\title{
Folklore of the Karaites in Lithuania: the Yehuda Bezekowicz Manuscript from Troki, $1873^{1}$
}

\author{
Piotr Muchowski \\ Adam Mickiewicz University
}

\begin{abstract}
The Heb $8^{\circ} 3652$ manuscript from the National Library of Israel is among a collection of rare manuscripts from $19^{\text {th }}$-century Lithuania containing unofficial Karaite literature. These manuscripts, including the Abkowicz 3 and JSul.I.05 manuscripts, contain a vast collection of texts relating to the practical cabbala. Some of them are typical of divination and magic literature, and many resemble parallel texts from the Cairo Geniza in their form and contents. Their presence in Karaite manuscripts is exceptional for theological reasons. The Karaite translations of these texts were presented by professor Ananiasz Zajączkowski in the inter-war period as representative evidence of Karaite folklore and folk literature. This article includes an introductory presentation of the Heb 8.3652 manuscript. ${ }^{2}$
\end{abstract}

\section{Keywords}

Karaite folklore, Hebrew divination and magic literature, practical cabbala, Troki, Yehuda Bezekowicz

\section{The copyist}

The manuscript was copied by Yehuda Bezekowicz. ${ }^{3}$ In the catalogue of the National Library of Israel, it is entitled 'Osep liqqutim šonim. It is one of the manuscripts which Abraham Kahana purchased from Yehuda Bezekowicz's widow. The other two manuscripts copied by Bezekowicz in the Kahana col-

\footnotetext{
1 I would like to express my thanks to professor Gideon Bohak for reading a draft of this paper and the improvements he made to it.

2 This manuscript was recently discussed by Gideon Bohak, cf. Bонак 2013

3 The surname Bezekowicz is also known in the variants: Biezikowicz and Bieziekowicz.
} 
lection are quoted by Jacob Mann in Karaitica. ${ }^{4}$ They were marked by him as Kahana I and Kahana II, respectively. ${ }^{5}$ At present, three other manuscripts copied by Bezekowicz, all held in the collection of the National Library of Israel, are known to exist. Two of them are marked as Piyyutim (NLI $8^{\circ} 5195$ and NLI $\left.8^{\circ} 5205\right)$. The first was copied in Troki in 1903 and the second in Simferopol in 1906. The third, 'Aqedat Ișhaq (NLI $8^{\circ} 5209$ ), was copied in Troki in 1871.

On the first leaf of the manuscript $8^{\circ} 3652$, there is a graphic symbol in the shape of the Magen David, with the name of the copyist written inside:

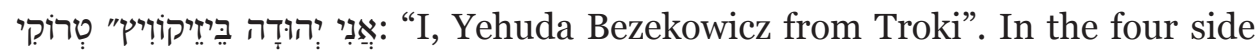
arms, characters providing the date of the copying were placed "633" (תרל"ג), i.e. 1873. There are also two records on its origin in the manuscript. On page $15 \mathrm{v}$, there is a colophon:

$$
\begin{aligned}
& \text { ע"כ מצאתי והעתקתי אני הצעיר = } \\
& \text { יהודה בן לא"א היקר כ"מ שלמיאל זכיר הכריה יצ"ו }
\end{aligned}
$$

"Thus far I have found it and copied it, I, young Yehuda, the son of my lord, my father respectable, honourable Highness, Shelumiel Zakharya, may his Rock and his Saviour guard him”.

And on folio 2r, the following note (it follows a short paragraph about totafot, which is a quotation from Keter Tora by Aharon ben Eliyyahu of Nicomedia ${ }^{6}$ ):

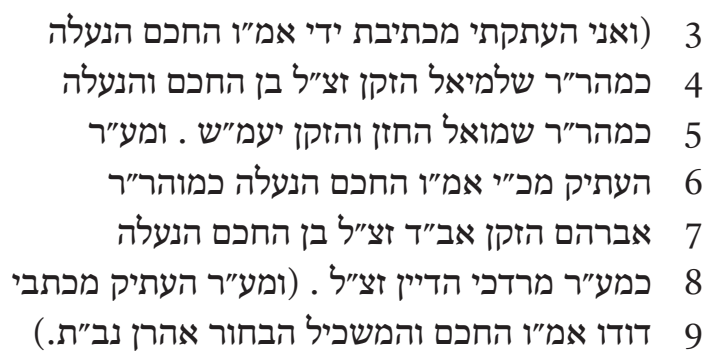

4 Cf. Mann 1935: 554, note 7.

5 Copied in 1902 and 1903. On the first leaves of these manuscripts, there are also the titles: Ma'asē haš-Šeni and Zemirot. The manuscripts are marked as Širim u-P̈iyyutim $8^{\circ} 5204$ (copied in 1903) and Qoveș Qara $i 8^{\circ} 3795$ (copied in 1902 and 1903) in the catalogue of the National Library of Israel.

${ }^{6}$ Cf. Aharon ben Eliyyahu of Nicomedia 1867: (Shemot) 35v. 
"(3) (I copied this from the manuscript of my lord, teacher and master, the dignified scholar, (4) honourable Highness, rav ribbi Shelumiel the elder, the memory of the righteous is a blessing, the son of the dignified scholar, (5) honourable Highness, rav ribbi Shemuel, the hazzan and elder, may he rest on his bed in peace. The Highness ribbi (6) copied it from the manuscript of my lord, teacher and master, the dignified scholar, our honourable great teacher, ribbi (7) Avraham, the elder, president of court, the memory of the righteous is a blessing, the son of a dignified scholar, (8) the honourable Highness, ribbi Mordekhay, the judge, the memory of the righteous is a blessing. (And the Highness ribbi copied it from the writings (9) of his uncle, my lord, teacher and master, scholar and sage, bachelor Aharon, may his soul rest in paradise)".

As can be seen from the above notes, Bezekowicz copied the text from the manuscript of his great-grandfather - Shelumiel ben Shemuel - probably not long after 1765. This information suggests that Shelumiel ben Shemuel 7 in turn copied the text from the manuscript of Avraham ben Mordekhay ${ }^{8}$ (Kapłonowski from Poniewież), who had copied the text from the manuscript of his uncle Aharon. Taking into account the fact that the name of Shelomo ben Aharon, the author of Seper Appiryon 'Asa Lo, is mentioned in the manuscript, we can assume that the text of the present manuscript came from the $1^{\text {st }}$ half of the $18^{\text {th }}$ century. Moreover, it is presently known from research conducted on the Abkowicz manuscript that manuscripts of the $17^{\text {th }}$-century Troki Karaites were the earliest source manuscripts. ${ }^{9}$

Relatively little is known about Yehuda (or Yufud) Bezekowicz. The information published by Mann ${ }^{10}$ comes from the colophons in the Kahana I and

\footnotetext{
7 He is mentioned in documents from 1775 published by Jacob Mann, cf. ManN 1935: 762763 (he was a bachelor at that time). He also appears in the 1765 census (Nowe Miasto, Poniewież, Poswól, and Sałaty): "The fifth house - Symon Sztefalewicz, teacher; Estera his wife; Salamon, Mojżesz - his sons.” National Library of Russia F 946 op. 9 (Polish deeds) no. 240.

${ }^{8}$ For more about Avraham ben Mordekhay, see MANN 1935: 745-763. In the above-quoted 1765 census: "The first house - Abram Kapłonowski, Szełomita - wife, Józef - son, Chana - daughter, Debora - nursing child, Sara Markiewiczowa - widow, mother, Abram Izakowicz - relative, Szałom Abramowicz - servant."

9 Cf. Muchowski 2013: 28-41.

${ }^{10}$ Cf. Mann 1935: 554, note 7.
} 
Kahana II manuscripts and from a note by Abraham Kahana. Mann cites this note imprecisely. Its content in the original Hebrew record reads as follows: ${ }^{11}$

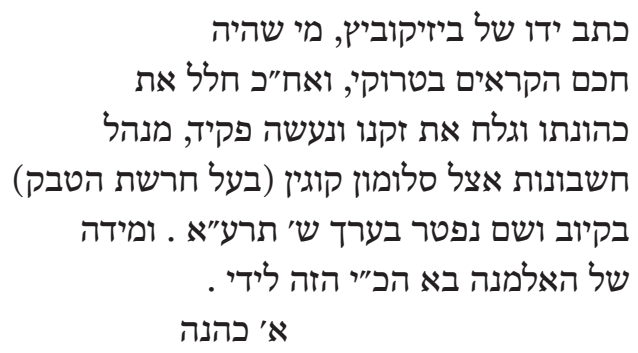

"The manuscript of Bezekowicz, the one who was a Karaite hakham in Troki, and later left his office, shaved off his beard and became an officer, an accountant with Salomon Kogien (the owner of a tobacco factory) in Kiev. And there he died about 1911. From the hands of his widow this manuscript fell into my hands. A. Kahana”.

The records of the Karaite Spiritual Consistory in Troki, where certificates regarding Bezekowicz were kept, have not been preserved. However, one file with a document concerning his appointment as a hazzan of the synagogue in Simferopol in 1905 was preserved; its contents include his personal data form from 1905 signed by the then hakham of Troki Romuald Kobecki. From the information included in it, we know that Yehuda (Yufud) ben Shelumiel Bezekowicz was born about 1859 (he was 47 years old in 1905). ${ }^{12}$ Therefore, in 1873 , when he copied the discussed manuscript, he was 15 years old. He finished primary school in Troki in 1874. In 1901, he was chosen as the elder hazzan of the synagogue in Troki. Previous places where he performed service are not mentioned; however, we can learn that he was a hazzan in Sevastopol from a document preserved in the records in the Taurida and Odessa Karaite Spiritual Consistory. ${ }^{13}$ He performed the duties of hakham of the Karaite Spiritual Consistory in Troki twice, from 1902 to 1903 and from 1904

${ }^{11}$ Cf. Heb. 8.5204, folio o verso.

${ }^{12}$ His name does not appear in the census of the Troki Karaites from 20 May 1858, cf. Lietuvos Valstybes Istorijos Archyvas 515.25.112, folio 532v, position 9, where his father Shelumiel ben Avraham was noted (aged 31).

${ }^{13} \mathrm{Cf}$. State Archive of the Autonomous Republic of the Crimea, F.241. Collection of the Taurida and Odessa Karaite Spiritual Consistory, op.1, call no. 610, p. 2. 
to 1905. It is not known under what circumstances this occurred, as Romuald Kobecki was the incumbent hakham in the period from 1902 to $1911 .{ }^{14}$ From 1905, Bezekowicz was a hazzan in Simferopol, probably until 1907. It is not clear what exactly happened afterwards. As follows from the note in Kahana's manuscript, he moved to Kiev and died there a few years later. It is noteworthy that Yehuda Bezekowicz was the editor of Tehillot Isra'el. ${ }^{15}$

\section{The manuscript and its contents}

The text of the manuscript was copied in Ashkenazi Karaite script characteristic of manuscripts from $19^{\text {th }}$-century Lithuania and Poland. It is semiformal in style, without ligatures and embellishments. The entire manuscript consists of 121 numbered leaves $(9 \times 15 \mathrm{~cm})$, including nine leaves which were left blank.

As for the literary genre, the manuscript displays features close to a florilegium and miscellany. It includes over 50 different textual units. However, if we mark out all the individual texts included in separate parts, i.e. also the short magic texts, then the total number is approx. 350. Many of them are excerpts from different literary works, usually biblical commentaries, and writings of a theological and philosophical character by Karaite and Rabbanite authors. They are very often quoted anonymously and without a title. Among the authors whose works are quoted in the Bezekowicz manuscript are noted Karaite and Rabbanite writers. Among them are Kalev Afendopolo, Ișhaq ben Avraham of Troki, Yosef ben Mordekhay Malinowski, Shelomo ben Aharon; Avraham Even Ezra, Shmuel Șarșa, Yișḥaq Abravanel, and Moshe ben Naḥman. The quoted texts of these authors are commentaries, aphorisms, riddles, etc. However, the largest group of texts in the Bezekowicz manuscript are texts belonging to the genre of magic and divination literature characteristic of the practical cabbala. These are texts such as: segullot, refu'ot, goralot, pitrone halomot, brontologion, re'amim u-re'ashim, simane matar, simane sha'are hat-tevu'a, hemerologion, kalandologion, onomantia, and others. As for their

${ }^{14}$ Cf. a mention of “B. p. Bogusław Firkowicz. Z powodu 10-ej rocznicy zgonu.” Myśl Karaimska 3, 1926, 17-18.

${ }^{15}$ Yehuda Bezekowicz, Ișhaq-Bo'az Firkowicz. 1909. Tehillot Isra'el. Tosafot li-Tefillot haqQara'im. Berdyczew. 
form and content, many of them are very much like the manuscripts from the Cairo Geniza. ${ }^{16}$

The textual material of the manuscript is about $70 \%$ percent identical to the material in the Abkowicz 3 manuscript. A comparative analysis shows that neither of the manuscripts was the prototype of the other. This is apparent in the language mistakes and mistakes of omission in the two manuscripts. At the same time, it seems that both were copied from the same initial source text. Texts on the following folios are analogous (with minor differences):

Heb 8.3652, fol. 15r, 1 - 4or, 10 = Abk 3, fol. 312r, $14-357$ r, 17

Heb 8.3652, fol. 47r, $1-51 \mathrm{v}, 13=$ Abk 3, fol. 370v, $1-375 \mathrm{r}$, 10

Heb 8.3652, fol. 53r, $1-64$ r, 6 = Abk 3, fol. 257r, $12-268 \mathrm{v}, 3$

Heb 8.3652, fol. 69r, $1-105$ r, 5 = Abk 3, fol. 268v, $4-311$, $14 .{ }^{17}$

The material which was not found in the Abkowicz 3 manuscript is the texts on folios $2 \mathrm{r}-12 \mathrm{r}^{18}$ (these are nine texts exegetic and cabbalistic in character which create separate sets with separate numbering) and the texts on folios 43r - 45r; 64r - 66r; 107r - 114v; and 115r - 121r.

The two quoted texts on folios $43 \mathrm{r}-45 \mathrm{r}$, under the common title "Sign and symptom from a sick person if he will recover", are attributed to Avraham ben Yoshiyyahu (1636-1687). On folio 43r we read: "From the writing of the eminent scholar, respectable rav ribbi Avraham the Doctor, the memory of the righteous is a blessing, the son of our respectable great teacher, ribbi Yoshiyyahu, the memory of the righteous is a blessing" ${ }^{19}$ The former provides a method of determining the outcome of a disease, whether it will end in death or recovery, on the basis of the day of the month on which the person fell ill; the latter, on the basis of the numerical value of the sick person's name, the day of the week and the day of the month on which the person fell ill. The former begins with: "If a person who is bedridden falls ill on (day) of the month, he will die soon. The outcome of an illness - death or recovery - depending

${ }^{16} \mathrm{Cf}$. Muchowski 2013: 7-8, 12-20. For the origin, literary genre, and social function of these works, cf. BоHAK 2013.

${ }^{17} \mathrm{Cf}$. Muchowski 2013.

${ }^{18}$ Barring two passages: one on folio $7 \mathrm{r}-7 \mathrm{v}$, which can be found in Abk 3 on folio 93r, and the other one on folio 8v, which occurs in Abk 3 on folio 95v (a cabbalistic square with the symbols of God's names). For more on two texts in this part ("Seven Steps" and "Intellectual Art”), see Вонак 2013: 23-25; 28-30.

מכתיבת החכם המופלא כהר"ר אברהם הרופא ז״ל בן כמוהר"ר יאשיהו ז״ל. 19 
on the day on which he was taken ill and the sign of the Zodiac". The latter one begins: "You who want to know about a sick person, whether he will live or die. The outcome of an illness on the basis of the numerical value of the sick person's name, the day of the week and the day of the month on which he was taken ill”. A diagram in the form of a circle showing the methods of calculation was attached to the texts (fol. 45r). Obviously, Avraham ben Yoshiyyahu is not the author of these texts; he might be merely the owner and the copyist of the original manuscript in which they were copied. The texts are not present in any of his preserved manuscripts, although there are several texts of the goralot, segullot and refu'ot type in them. ${ }^{20}$ The same diagram in the form of a circle can be found in a manuscript from the Biblioteca Medicea Laurentiana in Firenze (Plut. 44.1) in a work entitled Iggulim li-Qvi'at ham-Mazzal, fol. $14 \mathrm{r}$ (dated to the $13^{\text {th }}$ and $14^{\text {th }}$ centuries).

Folios 64r - 66r include a known divination text Dani'el 'iš Hamudot. The manuscript with the Karaite version from the end of the $19^{\text {th }}$ century from Poniewież was edited by Ananiasz Zajączkowski in 1938. ${ }^{21}$ The initial passage reads as follows:

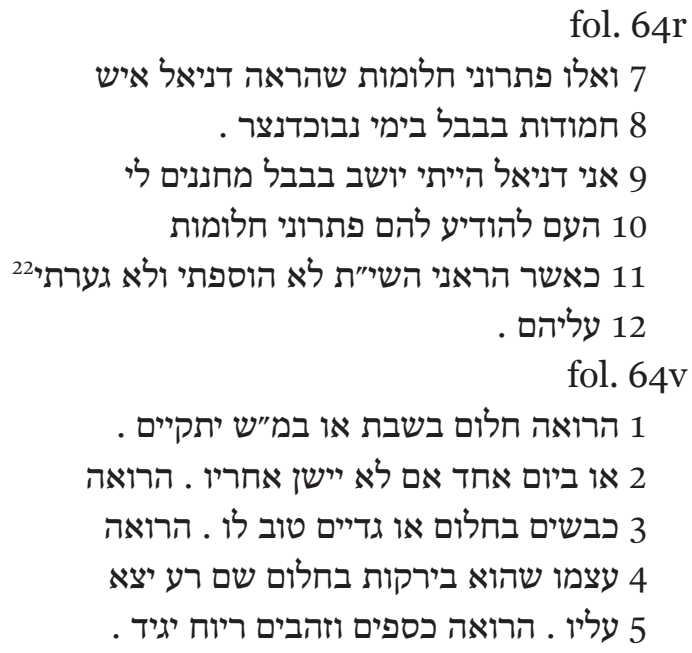

${ }^{20} \mathrm{Cf}$. Institute of Oriental Manuscripts B 263, folio 69r; B 263, fol. 79r; National Library of Russia Evr I 732, folio 57r.

${ }^{21}$ ZAJĄCZKOWSKI 1938: 42-50. The fragment is quoted in its Karaite version on p. 44 (Polish translation on p. 46).

${ }^{22}$ A copyist's error for: גרעתי. 
folio 64r: "(7) These are the interpretations of the dreams which Daniyyel, the beloved man, showed (8) in Babylon, in the days of Nebuchadnezzar. (9) I, Daniyyel, lived in Babylon. People begged me (10) to let them know the interpretations of dreams, (11) the way the Lord showed me, may he be praised. I have not added or reduced anything (12) from them.

folio 64v: (1) If a man has a dream on Shabbat or the evening after Shabbat - (this dream) will come true. (2) Or on a Sunday. Provided that he does not fall asleep after it. If a man sees (3) sheep or kids in his dreams (an omen) of something good for him. If a man sees (4) himself in green in his dream - (an omen) of him being calumniated. (5) If a man sees silver and gold - it predicts profit".

Folios 107r - 121r include two collections of short texts of the segullot type. These texts could not be found in other manuscripts. Additionally, their source text remains unknown. The first collection $(107 \mathrm{r}-114 \mathrm{v})$ includes 39 numbered texts. Their textual character is well illustrated by the initial ones, quoted below:

$$
\begin{aligned}
& \text { fol. } 107 \mathrm{r} \\
& 11
\end{aligned}
$$

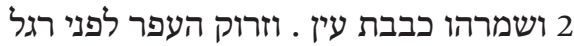

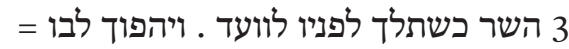

$$
\begin{aligned}
& 4 \text { משנאה לאהבה . או זרוק לפני הרצח לועד ויהפוך לבוים }
\end{aligned}
$$

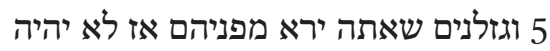

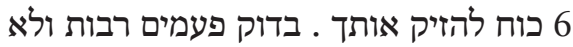

$$
\begin{aligned}
& 7 \text { יערכם זהב וכסף . } \\
& 8 \text { } 2 \text { כשתפחד מהשר או מסף מהשופט או המושל כיל }
\end{aligned}
$$

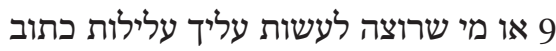

$$
\begin{aligned}
& 10 \text { שמו על הנייר . ואח"כ כתוב שפות שמו בהפי שפילות כתוב . } \\
& 11 \text { ואמור כשהפכתי את שמו כיר כי כת יהפוב שמוך לבו }
\end{aligned}
$$

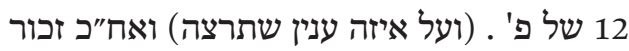

$$
\begin{aligned}
& 13 \text { שמו תוך בתי הקברות ויועיל . בדוק ומנוסה . }
\end{aligned}
$$

folio 107r: "1. (1) Burn a firstborn male cat in a clay dish to ashes (2) and guard it like the apple of your eye. Throw the ashes before the ruler's foot (3) when you go to a meeting with him. His heart will change, (4) from 
hatred to love. Or throw before murderers (5) or robbers of whom you are afraid, and then they will have no (6) power to hurt you. Checked many times and no (7) gold or silver can be compared with them.

2. (8) When you are afraid of a ruler, or a judge, or an authority, (9) or anyone who wants to harm you. Write (10) his name on paper, and afterwards write his name backwards. (11) And say: Like I changed his name, so let the heart of so-and-so change (12). (In any case desired) And then mention (13) his name in cemeteries. It will help. Checked and tested".

The other collection (folios $115 \mathrm{r}-121 \mathrm{r}$ ) consists of 27 numbered texts. The first two read as follows:

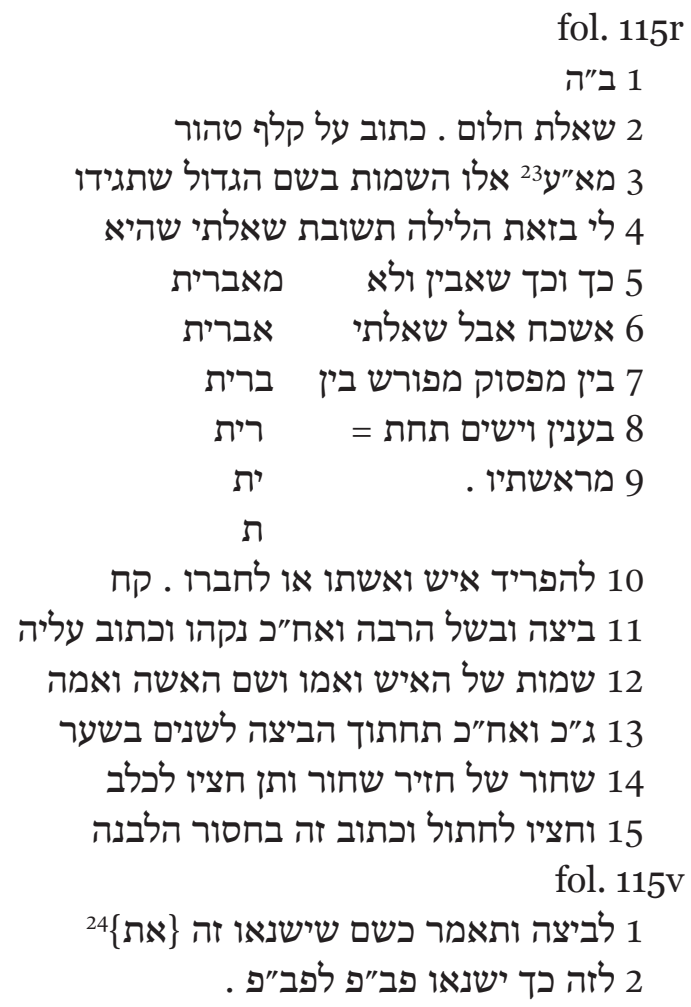

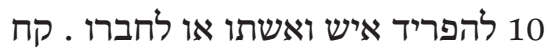

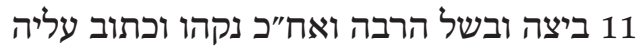

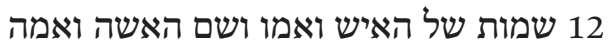
13 ג״”כ ואח"כ תחתוך הביש ואמושה לשנים בשער

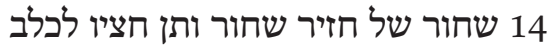
15 וחציו לחתול וכתוב זה בחסור הלבנה ותור לכלב fol. $115 \mathrm{v}$

1 לביצה ותאמר כשם שישנאו זה (את) 24

2 לזה כך ישנאו פב"פ לפב"פ .

\footnotetext{
${ }^{23}$ An abbreviation for משביע אני עליכם.

${ }^{24}$ The word was written by mistake and crossed out.
} 
folio 115r: 1. "(1) With God's help. (2) A dream request. Write on pure leather: (3) I adjure you, Names, by the greatest name, to give me an answer (4) on this night to my question, which is (5) such and such. So that I understand and do not (6) forget, but ${ }^{25} . .$. my question, (7) whether through a clear verse, ${ }^{26}$ or (8) one regarding an issue. Put it under (9) the bed-headboard. (A triangle with the "vanishing" name מארבית was placed on the left side of the text: $M^{`} B R Y T$, 'BRYT, BRYT, RYT, YT, T. $)^{27}$

2. (10) To separate a man from a woman or a friend. Take (11) an egg and boil it well. Then clean it and write on it (12) the name of the man and his mother, and the name of the woman and her mother (13) as well. And next cut the egg in half with a black hair (14) of a black pig and give a half to a dog, (15) and a half to a cat. And write this while the moon is waning

folio 115v: (1) on the egg and say: Like these hate (2) each other, may such and such, the son of such and such (hate) such and such, the daughter of such and such".

\section{The practical cabbala in the Karaite community}

The textual material in Bezekowicz's manuscript requires special commentary with reference to the status of magic and divination literature in the community of the Polish-Lithuanian Karaites (while keeping in mind that mystic practices were one of the reasons for the schism between Karaites and Rabbanites $^{28}$ ). When considering this issue, we should, first of all, refer to three well-known articles by Ananiasz Zajączkowski, one of the best-known representatives of the Karaite community in Poland in the $20^{\text {th }}$ century, a Turkologist and professor of Warsaw University. They appeared in Myśl Karaimska

\footnotetext{
${ }^{25}$ Some words are probably missing here.

${ }^{26}$ I.e., by making me dream of a biblical verse which will provide a clear answer to my question.

${ }^{27}$ Cf. BOHAK 2013: 25-26.

${ }^{28}$ Cf. HARARI 2007: 82-87.
} 
during the interwar period. ${ }^{29}$ Zajączkowski edited three texts from the genre of divination literature in them, "Fortune-telling from Twitches in Parts of the Body" ${ }^{30}$, "Dream Interpretations" ${ }^{11}$ and "Book of Lots" ${ }^{2}$. All texts were written in the Western-Karaite language and come from late $19^{\text {th }}$-century manuscripts. In these articles, Zajączkowski proves that the texts are an expression of the folk literature of the Karaites in Lithuania, although he attributes their origin to either the folklore of Turkic peoples or the general heritage of Turkic and Middle-Eastern peoples. ${ }^{33}$ It is relevant that Zajączkowski confirms that these and similar works were spread among the Karaite community in the Karaite language, and he recognizes them as an expression of the authentic folklore of the Lithuanian Karaites. In his opinion, these texts were brought from Crimea. However, all three texts published by Zajączkowski are actually translations from the Hebrew language. They are translations of texts entitled: Seper

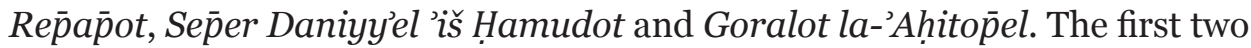
were attested in the very same textual version in the Bezekowicz manuscript, and one of them, i.e. Seper Rep̄ap̄ot, is also in the Abkowicz 3 manuscript. ${ }^{34}$ The third one is known from a Hebrew Karaite manuscript from Lithuania held in the Firkowicz collection, dating to the $17^{\text {th }}$ century ${ }^{35}$ Clearly, all of them originated in cabbalistic Hebrew literature, from the genre of divination literature, and had spread throughout Europe since the Middle Ages. These texts entered the community of the Polish-Lithuanian Karaites in the $17^{\text {th }}$ century. ${ }^{36}$

${ }^{29}$ See ZAJĄCZKowski 1929: 23-31; ZAJĄCZKowski 1935-1936: 24-29; ZAJĄCZKowski 1937-1938: 41-59. Cf. Muchowski 2012.

30 "Wróżby z drgania części ciała". Cf. ZAJĄCZKowski 1929: 23-31; ZAJĄCZKowski 1935-1936: 24-36.

${ }^{31}$ "Wykładanie snów". The initial fragment of the work is quoted above. Cf. ZAJĄCZKowski 1938: 42-50.

32 "Księga losów". Cf. ZAJĄczKowsKi 1935-1936: 36-39.

33 These hypotheses, which were described in Zajaczkowski's articles, seem to reflect the new cultural policy of the authorities of the Karaite community in Poland after the First World War. This policy was consequently carried out since the time Seraya Shapshal assumed the office of hakham of the Polish Karaites in 1928. It was manifested in, among other things, the new, officially announced, definition of the national identity of the Karaite community as the Karaite nation of Turkic origin.

${ }^{34}$ In the Firkowicz collection, both texts were found in the manuscripts NLR Evr I 266-267 and NLR Evr I 268-269 (dated to the $15^{\text {th }}$ and $16^{\text {th }}$ centuries). Cf. Muchowski 2012.

35 NLR Evr I 265. Cf. Muchowski 2013: 30-31.

${ }^{36}$ For details on the circumstances of their spreading into the community of the Lithuanian Karaites, see Muchowski 2013. According to Simha Lucki, cabbalistic ideas arrived in the 
In the $18^{\text {th }}$ and $19^{\text {th }}$ century, they found a permanent place in the unofficial literature of the Polish-Lithuanian Karaites. In the $19^{\text {th }}$ century, their Karaitelanguage versions became popular, as well. This was probably caused by the linguistic situation and changes in the Karaite educational system in the latter half of the $19^{\text {th }}$ century. From the end of the $19^{\text {th }}$ century, the knowledge of Hebrew in the Karaite community of Eastern Europe was clearly in decline. In the article "Folklore Texts and Studies" (part 2: "Folk Medicine"), from 1938, Ananiasz Zajączkowski also edited several refu'ot texts in the Karaite language and depicted some of the magic practices of the Karaites in Lithuania. ${ }^{37}$ Abraham Gottlober mentioned the magic practices of the Polish-Lithuanian Karaites, as well. According to his account, the Karaites in Halych used to write protection amulets for children. ${ }^{8}$ It is also known from contemporary verbal transmission that practices of the goralot type were still alive in Lithuania in the $2 \mathrm{O}^{\text {th }}$ century. That state of affairs in regards to divination practices seems to be confirmed by two notes found in the records of Karaite regional councils in Lithuania, which were edited by Jacob Mann. ${ }^{39}$ The first of these can be found in a record from 1665 , the other from 1776 . They read as follows: "Do not turn to the spirits of the dead and soothsayers. The punishment of the intentional sinner is great" ${ }^{40}$ A remainder of prohibited practices ${ }^{41}$ doubtlessly

Karaite community in Lithuania as early as in $16^{\text {th }}$ century; cf. Simha Lucki, Livnat hasSappir: haš-ša'ar haš-šeliši (Institute of Oriental Manuscripts B 307, fol. 7v - 9r).

${ }^{37} \mathrm{Cf}$. ZAJĄCZKowsKi 1938: 50-59.

${ }^{38}$ See GotTLOber 1865: 13 .

${ }^{39}$ See MAnN 1935: 831 (Resolutions of Meeting in 1665 C.E.), 964 (Resolutions of the Assembly of the Lithuanian Karaites (1776 C.E.). Cf. also Mann 1935: 1005.

שלא לפנות באובות וידעונים והמזיד ענשו גדול 40 . Mann interpreted this as "Probably referring to gypsies who acted as palmists and soothsayers”. Cf. MANn 1935: 964, note 926a.

${ }^{41}$ On the official position of Karaite theology on magic practices, see Eliyyahu Bashyatchi, Seper ham-Mișvot han-Niqra' 'Adderet 'Eliyyahu, 'Inyan 'Avoda Zara, chapter 2 (1834 Gözleve edition: 52r). The prohibition of these practices (which were described as "idolatry" or the "nine abominations") is derived from Deut. 18:10-11 and Lev. 19:28. Bashyatchi explains the meaning of the terminology used to name types of forbidden idolatrous practices. He mentions, among others, throwing lots on sand or paper in order to learn the course of events, associating activities with specific times, fortune-telling from a bird's shriek, and refraining from action as a result of specific events (for example: "I have seen someone today, that is why I will not eat or mount a horse"; "a piece of bread has fallen out of my mouth, I will not go to some place”), using spells with the use of God's name to achieve a goal (for example "bewitching animals - a serpent or a scorpion to protect against their sting”). In Bashyatchi's conclusion, there is a polemical reference to Maimonides, who allowed mystical practices as a remedy in mental therapy, cf. HARARI 2007: 98. 
underlies this brief entry, which must have resulted from some specific events. In respect to the interpretation of the terms which belonged to the group of the so-called "nine abominations" mentioned in Deut. 18:10-11, it seems that the most important commentary in this context can be found in Keter Tora of Eliyyahu from Nicomedia, which says that the term yidde'oni might refer to the practices of the goralot type (cit. "They say that it is someone who throws lots or points"). ${ }^{42}$ This commentary dictates an interpretation of the two quoted notes in the records of Karaite regional councils, namely that they are a condemnation of divinatory practices. This clearly suggests that those practices had to exist as a social fact which required an official response. ${ }^{43}$

${ }^{42}$ Cf. Aharon ben Eliyyahu of Nicomedia 1867: (Devarim) fol. 21v):

ושואל אוב : הוא פיתום כענין והיה כאוב מארץ קולך (ישעיהו כט) ונתבאר ענינו : וידעוני . אומרים שהוא

המפיל בגורלות ובנקודות.

The one who asks 'ov. It is the Python. Like in the issue: "Your voice will be like that of a spirit ( $k e^{-} \mathrm{ov}$ ) from the ground (Isa 29:4). And the meaning of this was explained. And the yidde'oni. They say that it is someone who throws lots and points". Cf. Lev 20:27. Cf. also B Sanhedrin 65, 1:

בעל אוב - זה פיתום המדבר משחיו, וידעוני - זה המדבר בפיו. הרי אלו בסקילה.

" $B a^{c} a l$ ' $\mathrm{ov}$ - it is the Python who speaks from his armpit. The yidde'oni - it is the one who speaks from his mouth. These should be stoned.

Cf. also Yehuda Hadassi, Sep̄er 'eškol hak-Kop̄er, chapter 103 (in the 1836 Gözleve edition fol. 43r):

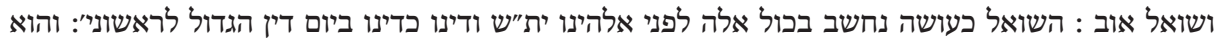

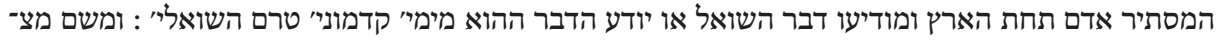

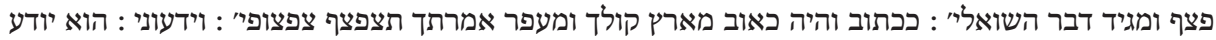

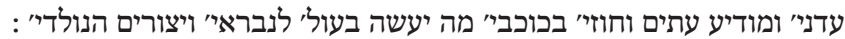

The one who asks 'ov is considered before our God - may His Name be praised - to be equal to him who does all these (abominations). A judgment on him will be the same as on the day of great judgment of the first ones. And (similarly is guilty) he who buries a man below ground and informs him about the inquirer's matter, or he who knows this matter from the old times, earlier than the inquirers - and from there (i.e. below ground) he screams and tells (an answer to) the matter of the inquirers. As it was written: "Your voice will be like that of a spirit from the ground, and your speech will whisper from the dust (Isa. 29:4)". And the yidde'oni. He knows periods and informs about times. And (equally yidde'onim are) those who look at the stars what in the world will happen to the created beings and the creatures who are born".

${ }^{43}$ In this context, it also is noteworthy that in Pinkas Bet-Din of Troki (for this pinkas, see Muchowski 2013: 21, note 11), there is a passage, copied about 1819, from the treatise Pitron Halomot by Shelomo Almoli. The quotation is from its first gate and first chapter, and the relevant text starts with "A person standing on a mountain. If somebody sees himself walking up a mountain, he will achieve high dignity". It is, however, not clear what the reason was for its being copied into the pinkas of Bet Din. 
In conclusion, it should be emphasised that the Heb 8.3652 manuscript is undoubtedly an expression of the real influence of the practical cabbala in the community of the Polish-Lithuanian Karaites, which is well evidenced since the $17^{\text {th }}$ century. Nonetheless, members of the Karaite community were well aware of the fact that such texts and the practices associated with them were strictly forbidden in Karaite Judaism. Apparently, they read, copied and kept them in violation of official bans (which can be seen in at least a few manuscripts from the $19^{\text {th }}$ century ${ }^{44}$ ). It can be concluded on the evidence of preserved accounts that such practices had a limited scope and were restricted to fortune-telling and protection. As articles published by Zajączkowski show, works from this genre entered Karaite folk literature for good.

\section{Bibliography}

[Anonymous]. 1926. B. p. Bogusław Firkowicz. Z powodu 10-ej rocznicy zgonu. Myśl Karaimska 3, 17-18.

Aharon ben Eliyyahu of Nicomedia. 1867. Sep̄er Keter Tora, Gözleve.

BaSHYATCHI, Eliyyahu ben Moshe. 1834. Sep̄er ham-Mișvot han-Niqra’ Adderet Eliyyahu. Gözleve.

Вонак, Gideon. 2013. Rabbanite Magical Texts in Karaite Manuscripts. Karaite Archives 1, 17-34.

Gottlober, Abraham, Beer. 1865. Bikkoreth ŁeToldoth Hakkaraim. Fünn et Rozenkrancz: Wilno.

HADASSI, Yehuda. 1836. Sep̄er 'Eshkol hak-Kō̄er. Gözleve.

HARARI, Yuval. 2007. Leadership, Authority, and the "Other" in the Debate over Magic from the Karaites to Maimonides. The Journal for the Study of Sephardic and Mizrahi Jewry 1, 79-101.

Mann, Jacob. 1935. Texts and Studies in Jewish History and Literature. Volume II: Karaitica. Philadelphia: Hebrew Press of the Jewish Publication Society of America.

\footnotetext{
${ }^{44}$ When considering the scale of the phenomenon, it should be taken into account that at the time when Yehuda Bezekowicz copied the discussed text, there were about 40 Karaite houses in Troki and the whole community consisted of about 200 people.
} 
Muchowski, Piotr. 2012. Notes on Two Karaite Texts Edited by Ananiasz Zajączkowski. Folia Orientalia 49, 327-337.

- 2013. Folk Literature of the Polish-Lithuanian Karaites: Abkowicz 3 Manuscript, Part 2. Editions Suger Press, Revue Européenne des Etudes Hébraïques: Paris.

ZAJĄczkowski, Ananiasz. 1929. Wróżby z drgań części ciała. Myśl Karaimska 2/1, 23-31.

- 1935-1936. Z dziejów literatury wróżbiarskiej: I Objaśnienia drgań części ciała, II Księga losów. Myśl Karaimska 11, 24-39.

- 1938. Teksty i studia folklorystyczne: I Wykładanie snów, II Lecznictwo ludowe. Myśl Karaimska 12, 41-59.

Piotr Muchowski is a professor in the Department of Asian Studies at the Adam Mickiewicz University in Poznan (in the section of Hebrew, Aramaic and Karaite Studies). His recent research focuses on the literature of the Karaites in the Polish-Lithuanian Commonwealth. 